\title{
The Quality of Adjudication: Reviewing the Settlement of Criminal Cases by the Judges
}

\author{
Syakir \\ Faculty of Law, Universitas Tomakaka Mamuju, West Sulawesi, Indonesia. \\ Minta Jaya Ginting \\ Faculty of Law, Universitas Tomakaka Mamuju, West Sulawesi, Indonesia. \\ Muhammad Irwan \\ Faculty of Law, Universitas Tomakaka Mamuju, West Sulawesi, Indonesia
}

\begin{abstract}
In the development of the community, the law must be able to follow the development of the community as well. Judicial work, in contrast, is based on legislation and on the expertise of the personnel. The type of research is juridical-empirical research or a socio-legal research, which examines the legal provisions and what happens in communities. The research approach uses conceptual and cases approaches. The results show the principles of justice in the decision to resolve a criminal case by a judge in a court are sentenced through a court decision which must at least contain two aspects of justice, namely procedural justice and substantive justice. Procedural justice is justice related to the protection of the legal rights of the parties in each stage of the judicial process. Meanwhile, substantive justice is related to the content of judges' decisions in adjudicating a case, which is made based on objective, honest, impartial and rational-logical considerations. The settlement of justified criminal cases and the role of judges in achieving these values through judges' decisions in court is carried out by judges with the obligation to base their decisions on legal considerations that contain sociological, juridical, and philosophical values.
\end{abstract}

Keywords: Adjudication; Criminal Law; Court; Judges

DOI: $10.7176 / \mathrm{JAAS} / 59-04$

Publication date: December $31^{\text {st }} 2019$

\section{Introduction}

Indonesia is a constitutional law, so that it cannot be seen as textual only. However, the law exists for society not for the opposite, therefore it should be dynamic and in accordance with the law that lives in the community (as a living law), ${ }^{1}$ in the sense that in the development of the community, the law must be able to follow the development of the community as well. Certainly, the law must be coming from communities or cultures so that it does not tend to impose but a natural awareness born of the person as good something to be independent and humane.

Judicial work, in contrast, is based on legislation and on the expertise of the personnel. That being said, judicial work can also be viewed as a form of service provision. In this context, the judge occupies the most strategic position in creating justice through its verdict. This is in accordance with the opinion of George F. Cole that the judge is the most important figure in the criminal court. Decisions of the police, defense ottorneys and prosecutors are greatly affected by judges in rulings and sentencing practices. ${ }^{2}$ Therefore, the main task of the judge is to try, examine and decide a case.

The law can not be seen as something final (finite scheme), but the law must keep moving, changing, following the dynamics of human life. Therefore, the law must continue to be dissected and explored through progressive efforts to reach the light of truth in achieving the noble goal of justice. Humans as important and main actors behind the life of the law are not only required to be able to create and carry out the law (making the law), but also the courage to breaking the law when the law is not able to bring the spirit and substance of its existence, namely creating harmony, peace, order and community welfare. The existing reality so far, the law is understood only limited to the formulation of the law, law enforcement officials are pragmatic which only positions themselves as mouthpieces of the law without any room and willingness to act progressively.

The judge in examining, adjudicating and deciding a case must first use the written law as the basis for their decision. If in the written law is not enough, it is not appropriate to the problem in a case then the judge seeks and discovers their own law from other legal sources such as jurisprudence, doctrine, treaties, customs or

\footnotetext{
${ }^{1}$ Z Aspan and A Yunus 2019 The right to a good and healthy environment: Revitalizing green constitution IOP Conf. Ser.: Earth Environ. Sci. 343012067

${ }^{2}$ George F. Cole, The American System of Criminal Justice, Brooks/Cole Publisihing Company Pacific Grove, California, 6th Edition, 1992, p. 470.
} 
unwritten law. Act No. 48 of 2009 Article 10 paragraph (1) on the Judicial Power states that "the court is prohibited from refusing to examine, adjudicate, decide upon a case that is proposed with the reason of absent or unclear legal, but obliged to examine and adjudicate it."

The provisions of this article indicate that the judge as the main organ of the court and as the executor of the judicial authority is obligatory to find or discover the law in a case even though the legal provisions are absent or unclear. However, either the creation of law or the discovery of law by the judge in its consideration must be attached to a number of restrictions, namely considerations based on norms, morals, and doctrines ${ }^{2}$ can give meaning to the rules that are already exist.

Judge by its position (ambtshalve) is not just a mouth or a law horn (bouche de la loi) but being a translator or interpreter through legal discovery, or legal construction in the form of interpretation, even creating a new law (rechtsschepping) through the sentencing. The substance of legal discovery for the judge is a serious effort to find the law in concreto, and therefore a judge has a comprehensive collection of legal knowledge in abstracto.

In line with this, Cardozo, ${ }^{3}$ once stated that my duty as judge say to be objecity in law, not my own aspirations and convictions and philosophies, nut the aspirations and convictions and philosophies of the men and women of my time. hardly shall I do this well if my own sympathies and beliefs and passionate devotions are with a time that is past.

Based on the example of the judge's decision above, of course, we need to examine more deeply whether the opinions about these decisions are considered controversial because they do not meet the sense of justice in the community or even those decisions to ensure the upholding of justice and protection of human rights. In the framework of legal philosophy, some of the cases above are not only limited to grammatical issues. The Philosophical Framework invites legal thinkers to examine problems holistically. It is not only fixed on normative rules and language narrowness, but must be widely analyzed in terms of ethics, morality, and humanity, through critical approaches. Are the Judges' decisions in criminal cases so influenced by the philosophy of natural law, realism, or deep in the minds of positivism?

\section{Method of the Research}

The type of research is juridical-empirical research or a socio-legal research, which examines the legal provisions and what happens in communities. ${ }^{4}$ The research approach uses conceptual and cases approaches.

\section{Implementing Living Law on Criminal Law in Realizing a Justice}

As regards judicial work, it should be kept in mind that the assessment of the quality of the process cannot be based merely on whether the customer is happy or unhappy. Court proceedings and adjudication are activities that are bound by the law and marked by impartiality and the equal treatment of all comers. Meanwhile, targets in legal studies are norms or rules, namely a set of commands about what to do, and a prohibition on what not to do. In addition, legal discovery is also a target in legal studies. This is because the legal order is not perfect, the law must be discovered. ${ }^{5}$

The court's decision to restore the previously unfair situation, which occurred because of a violation of the law to the original state (restitutio in integrum) ${ }^{6}$ That is the culmination of law enforcement which is a crucial decisive function in realizing justice to become a reality in everyday life. Law enforcement carried out by the court, the form of the mechanism and procedure is greatly influenced by the legal system adopted by a community or country where the law applies

The legal is not merely a law, but also a habit or values that live in society. The judge, however, as law enforcement is not just a law horn (la bouche de la loi), but it is not a trumpet that blow freely by society (la bouche de society). ${ }^{7}$ The judge stands balanced in its middle has the right to interpret the law and is obliged to explore the sense of justice that lives in communities. However, justice in the discoveries and judgments of

\footnotetext{
${ }^{1}$ In the Latin adage, it is known as "Ius Curia Novit" that can be used as legal principles and contained in the Civil Code, which is part of Code Napoleon in France. At first the principle was interpreted narrowly, namely "the judge may not refuse to examine the case by the reason of absent or unclear legal." This interpretation is based on a growing belief at that time, that the codified written law has completely contained rules about all legal events and legal relations that may occur in all aspects of human life. But then it turned out that the codified law was never complete and was always left behind by developments in society. Therefore, the principle was interpreted broadly, namely giving authority to the court (judge) to discover the law (rechtsvinding) to adjudicate the case that was brought to him, when the codified law had not regulated it.

${ }^{2}$ The results of research on the Judges' Verdict on Human Rights as conducted by the Judicial Commission with the Norwegian Center for Human Rights and the Center for Law and Human Rights Studies at the University of Indonesia, on the conclusion of page 70 stated "the judges rarely apply legal doctrines as a basis for legal considerations in the decision he made."

${ }^{3}$ Muladi, Demokratisasi, Hak Asasi Manusia, dan Reformasi Hukum di Indonesia. Habibie Center, Jakarta, 2002 , p. 224.

${ }^{4}$ Sulistyowati Irianto and Sidharta, Metode Peneiitian Hukum; Konstelasi dan Refleksi, Jakarta, Yayasan Obor Indonesia, 2011, p. 177.

${ }^{5}$ Sudikno Mertukusumo. 2004, Penemuan Hukum Sebuah Pengantar, Liberty, Yogyakarta. p 2.

${ }^{6}$ John Rawls, 2006, A Theory of Justice, Teori Keadilan Terjemahan Uzair Fauzan dan Heru Prasetyo,Pustaka Pelajar, Yogyakarta, p. 72

${ }^{7}$ Achmad Ali. 2002. Menguak Tabir Hukum. Gunung Agung Jakarta. Second edition. p. 73
} 
judges will not be achieved without legal instruments as the basis of independence and judicial power.

Legislation has many problems were not flexible, never complete to cover all legal events or lawsuits and bring about what is commonly called legal vacuum or rechstvacuum. Precisely is the void of legislation being not a legal vacuum. The weaknesses of these legislations then require a concept of legal discovery by judges although in some cases the discovery is limited to justice. Legal vacuum is very easy occurs if the law source only is the law. The role of judge is required and not just as a law trumpet.

In order to fill this legal vacuum, the judge has the authority to interpret but specifically to criminal justice, analogy is not allowed. The authority of the judge to legal discovery is also a consequence of the judicial principle in which "the court shall not refuse to examine, adjudicate, and decide on a matter by the reason that absent or unclear legal but it is obligatory to examine and adjudicate it." In interpret a rule of law, the judge should refer to several principles, as follows:

a. Principle of objectivity which implies that interpretation should be based on the literal meaning and nature of the rule of law and must be made clear so that it can be used for further development.

b. Principle of unity which implies each norm should be read as one unseparated text.

c. Principle of genetic which implies in interpreting, the existence of the original text should be the primary consideration as well as the grammatical, cultural and social conditions of the establishment of the law and the intent of the law makers.

d. Principle of comparison which implies in discovering needs to be compared with other legal texts about the same thing at a time.

A legal discovery by a judge referring to the four principles above may give rise to a verdict that provides legal certainty, justice and prosperity in the community. The criminal law in communities is intended to provide a sense of security to individuals and groups in their daily activities. Article 1 paragraph (1) of the Criminal Code which reads "no act punishable, but on the strength of the criminal provisions in the law existing in advance of that act" the principle of legality is the basis for determining whether any criminal offense shall be set beforehand by a rule of law or at least by an existing rule of law or before the person commits an act.

The principle of legality is a principle that states that no act can be punished, except on the basis of the strength of criminal provisions according to the existing Act first in advance. ${ }^{1}$ Actions that can be punished are divided into positive actions, it means as "doing something." While, negative actions are intended "not doing something." 2

Not doing something that is obligatory and doing something that is prohibited is a criminal offense. Meanwhile, according to Moeljatno that the criminal provisions according to the Act, if referring to Article 1 of the Criminal Code, means the criminal rules in the legislation. ${ }^{3}$ It can be concluded that the principle of legality is a concrete legal regulation whose meaning is contained in the Criminal Code of each country as a standard definition of the principle of legality itself. ${ }^{4}$

Legal discovery is an activity that conducted by judges (in their duties) and also by people working in the legal field, such as lecturers, prosecutors, lawyers, and people who work in law firms, in solving legal problems. It is a deductive argument, from a concrete rule of law as a major premise, legal event as a minor premise, and the legal discovery itself in the form of judge decision as a conclusion.

If rests on the principles of criminal law interpretation, four of the seven principles, namely the principles of proportionality, relevance, compliance, and material are more directed to unwritten rules and constantly evolving in the community. ${ }^{5}$ Even if we refer to some jurisprudence, there are decisions of judges who make legal discoveries with extensive interpretation methods, which do not have a principal difference by analogy.

In criminal cases the decision-making is conducted by independent judges through a trial process. The process plays a role in determining how decisions will be made. On the other hand, decisions that are felt fair by the people depend on the fair, transparent and accountable trial process. All court decisions are legal and inkracht if they are said in open trial publicly. ${ }^{6}$

The basis of legal that used by the judge in sentencing a decision outside the article charged by the public prosecutor is through jurisprudence. There are several decisions of the Supreme Court that are guided by the judex factie, which then makes the decision guided by it become jurisprudence. When more tend to the justice, then the verdict of judge will rule out legal certainty. If following the provisions of Article 191 paragraph (1) of the Criminal Procedure Code, then the judge has set aside justice by releasing the defendant who has clearly been guilty of an offense despite his crime is not alleged.

\footnotetext{
${ }^{1}$ Eddy O.S Hiariej. Pemikiran Rammelink mengenai Asas Legalitas. Jentera Jurnal Hukum, Edisi 16 - tahun IV, April-Juni 2007 , p 124.

${ }^{2}$ T.J. Noyon \& G.E. Langemeijer, 1947, Het Wetbook Van Strafrecht. Vijfde Druk, Eerste Deel Inleiding Boek I, S. Gouda Quint - D. Brouwer En Zoon, Uitgevers Het Huis De Grabbe - Arnhem, pp. 54.

${ }^{3}$ Moeljatno. Asas-Asas Hukum Pidana. Rineka Cipta, Jakarta. 2000, Page. 26.

${ }^{4}$ Eddy O.S Hiariej. Asas Legalitas dan Penemuan Hukum dalam Hukum Pidana. Erlangga, Jakarta. 2009, p. 24.

${ }^{5}$ Ibid, p 84.

${ }^{6}$ Article 195 of Act No. 8 of 1981 on Criminal Procedural Law
} 


\section{Ideal Concept of Quality Management in the Indonesian Court}

Developing a dignified Indonesia is a conscious effort to improve the standard of living of Indonesian people, especially the development or improvement of the quality of human resources. Starting from law enforcement, corruption eradication, livelihoods, economic and social welfare, and human and humanitarian development efforts. The rules that used must be a rule refer to a social contract that has been agreed upon.

In a legal-based law enforcement requires various ideal approaches. Making legal discovery on criminal justice is also one of them. According to the author, there are several approaches needed in conducting legal discovery on criminal justice to realize a justice. In order to realize the vision of building Indonesia dignity, required an understanding of the subjects of the dignity is Indonesia human beings. The social fact of Indonesian peoples is plural, requires that by understanding the difference is the only solution so that we can unite. Self is true but it is possible become wrong. Others is wrong, but it is possible become true.

The basic principle can only be enforced through democracy. That every individual should be given the right to voice their aspirations and the individual must merge in the agreed upon social contract. Again, the rule of play about democracy as a way to unity the pluralism has been confirmed in the 1945 Constitution as the constitution of Indonesia. The constitution became the unification of the plural or diverse Indonesian nation.

For the constitution as the highest law in a State can serve in accordance with the will of the people, it must be built a constitution based on the views of life or the ideology of nation. Ideology is a reference to the formation of the nation' legal system, including its constitution. In the context of Indonesia, the constitution must be built on the ideology of the State and the Indonesian nation, namely Pancasila ideology. To realize good governance requires an organ in which the ideals can be carried out.

In a constitutional State, there are at least 12 (twelve) principles that constitute the establishment of the constitutional State in question. The twelve principles were law supremacy, equality in law, legality principle, restriction of power, independent organs of government, free and impartial courts, civil service arbitration tribunal, administrative judiciary, human rights protection, being democratic, serve as a means of achieving the objective of the State, as well as transparency and social control. ${ }^{\text {. }}$

The constitutional State and its twelve principles can be implemented as the national legal system. The system is an interrelated unity and work for the realization of a particular purpose. The legal elements are structure (institutional), substance (principle of rule), and culture (behavior of legal subjects determined by the principle of rules).

By involving the dimension of human rights, the 1945 Constitution can be said to be a human rights constitution that embodies the constitutional rights of citizens. In this argument, the discovery of law in criminal justice must be grounded. The discovery of law is intended for the protection of human rights, and the 1945 Constitution explicitly supports the constitutional rights of the citizens of that country.

The progressive law-based legal discovery is a legal discovery based on the character and progressive legal paradigm, including the presumption that the law is not an absolute and final institution, because the law is always in the process of being. Such a concept of law always encourages judges to decide cases contextually not only confined to the sound of the text of the Act alone.

On the other hand, it is supported by academics of law faculty at Leiden University, namely Van Vollenhoven, Ter Haar, and his students who are also from the native, namely Soepomo. The purpose of this group does not refuse codification and unification, they only refuse European cultural colonization of indigenous culture, including its legal system known as customary law. It was the hard efforts of this pluralist group which then maintained the existence of customary law until 1942 and became a seed for the birth of indigenous intellectual, especially law education. ${ }^{2}$ If person considers that in modern society, every problem is only the court as a way to settle the dispute, then it is a false assumption. there are still ways to settle disputes outside the court, including mediation, arbitration and consolidation.

Not all cases must be resolved in court. The United States is a country that has a lot of attention to the existence of courts and judges. Therefore, the concept of realism in the United States is so dominant. The realist approach has been charged as the cause of confusion and the excessive role of judges in forming and making laws. Such a view assumes that the law is not what the court does, but that the court is the institution that carries out the law.

If the judge tends to continue to follow the law, it will be very easy to predict what the judge decides in many cases. After all, the law is earlier than the court. A legal definition which states what the court decides is the same as saying that the drug is what written on a doctor' prescription paper. Judges' decisions that approach justice are not decisions that elicit placing judges as mouthpieces of the law, but judges must be able to interpret the actual law in accordance with the needs and developments that occur in the midst of community life but by still considering aspects of justice, legal certainty and the value of its usefulness.

\footnotetext{
${ }^{1}$ Teguh Prasetyo. Membangun Hukum Berdasarkan Pancasila. Nusamedia, Bandung.

${ }^{2}$ Soetandyo. 1990. Dari Hukum Kolonial Ke Hukum Nasional. Epistem Institute, Jakarta, p 29
} 


\section{Conclusion}

The principles of justice in the decision to resolve a criminal case by a judge in a court are sentenced through a court decision which must at least contain two aspects of justice, namely procedural justice and substantive justice. Procedural justice is justice related to the protection of the legal rights of the parties (suspects/defendants/ interested parties) in each stage of the judicial process. Meanwhile, substantive justice is related to the content of judges' decisions in adjudicating a case, which is made based on objective, honest, impartial and rational-logical considerations.

The settlement of justified criminal cases and the role of judges in achieving these values through judges' decisions in court is carried out by judges with the obligation to base their decisions on legal considerations that contain sociological, juridical, and philosophical values. Judges in the matter of resolving criminal cases for the sake of a decision that has a value of justice must be with the framework that the judge's decision made always prioritizes thoughts based on philosophical arbitration that this is made so that the judge's decision receives public legitimacy and can be accountable to the broader community.

\section{References}

Achmad Ali. 2002. Menguak Tabir Hukum. Gunung Agung Jakarta. Second edition. p. 73

Eddy O.S Hiariej. 2007. Pemikiran Rammelink mengenai Asas Legalitas. Jentera Jurnal Hukum, Edisi 16 tahun IV, April-Juni 2007.

Eddy O.S Hiariej. 2009. Asas Legalitas dan Penemuan Hukum dalam Hukum Pidana. Erlangga, Jakarta.

George F. Cole, 1992. The American System of Criminal Justice, Brooks/Cole Publisihing Company Pacific Grove, California, 6th Edition.

John Rawls, 2006, A Theory of Justice, Teori Keadilan (translated by: Uzair Fauzan dan Heru Prasetyo,Pustaka Pelajar, Yogyakarta.

Moeljatno. 2000. Asas-Asas Hukum Pidana. Rineka Cipta, Jakarta.

Muladi. 2002, Demokratisasi, Hak Asasi Manusia, dan Reformasi Hukum di Indonesia. Habibie Center, Jakarta.

Soetandyo. 1990. Dari Hukum Kolonial Ke Hukum Nasional. Epistem Institute, Jakarta.

Sudikno Mertukusumo. 2004, Penemuan Hukum Sebuah Pengantar, Liberty,Yogyakarta. p 2.

Sulistyowati Irianto and Sidharta, 2011. Metode Peneiitian Hukum; Konstelasi dan Refleksi, Jakarta, Yayasan Obor Indonesia.

T.J. Noyon \& G.E. Langemeijer, 1947, Het Wetbook Van Strafrecht. Vijfde Druk, Eerste Deel Inleiding Boek I, S. Gouda Quint - D. Brouwer En Zoon, Uitgevers Het Huis De Grabbe - Arnhem.

Teguh Prasetyo. 2014. Membangun Hukum Berdasarkan Pancasila. Nusamedia, Bandung.

Z Aspan and A Yunus 2019 The right to a good and healthy environment: Revitalizing green constitution IOP Conf. Ser.: Earth Environ. Sci. 343012067 